\title{
Anti-Inflammatory Activity of $S$. Marianum and N. Sativa Extracts on Macrophages
}

\author{
Maryam Bahrami ${ }^{1}$, Ali Ghazavi ${ }^{2}$, Ali Ganji ${ }^{3}$, Ghasem Mosayebi*3
}

\begin{abstract}
Background: Nigella sativa (N. sativa) and Silybum marianum (S. marianum) are used to regulate macrophage polarization in lipopolysaccharide-induced RAW 264.7 cells and thioglycollate-elicited peritoneal inflammation.

Methods: Cytotoxicity assays and acute toxicity tests were performed to investigate the safe dose and toxicity of the prepared extracts. Also, nitric oxide production was determined by Griess assay on RAW264.7 and peritoneal macrophage supernatants. After RNA extraction from macrophages, real-time PCR was performed to measure the relative gene expression of tumor necrosis factor (TNF)- $\alpha$, interleukin (IL)- 6 , transforming growth factor (TGF)- $\beta$, and IL-10. Finally, regulatory T cells (Treg cells) were counted by flow cytometry.

Results: S. marianum methanolic extract (SME), N. sativa ethanolic extract (NEE), and their mixture (SME+NEE) decreased NO levels significantly in RAW264.7 and peritoneal murine macrophages. $N$. sativa ethanolic extract significantly increased IL-10 gene expression and significantly decreased IL- 6 and TNF- $\alpha$ expression in RAW264.7 cells. In mixture-treated peritoneal macrophages, IL-10 and TGF- $\beta$ expression were significantly increased, while IL-6 and TNF- $\alpha$ were significantly decreased. Also, the percentage of Treg cells was significantly greater in the mixture-treated cells than in controls.

Conclusions: These results suggest that an SME and NEE mixture has anti-inflammatory and immunomodulatory activities and may be useful in the treatment of diseases of immunopathologic origin characterized by macrophage hyperactivation.
\end{abstract}

Keywords: Cytokine, Inflammation, Nigella sativa, Nitric oxide, Silybum marianum.

\section{Introduction}

Chronic inflammation has an important role in the creation, control, and exacerbation of a wide range of diseases including cancers and inflammatory and autoimmune diseases $(1,2)$. The main cells involved in inflammatory disease are macrophages, which participate in the inflammation process (2). Macrophages can be divided into two main groups referred to as classical (M1 or inflammatory) or alternative (M2 or antiinflammatory) macrophages. Classical macrophages play important roles in many inflammatory diseases through the production of interferon-gamma (IFN- $\gamma$ ), nitric oxide (NO), interleukin- (IL) 1, IL-12, and tumor necrosis factor- $\alpha(\mathrm{TNF}-\alpha)$, while alternative macrophages act as antiinflammatory cells by producing growth factor-beta (TGF- $\beta$ ) and IL-10 (2).

Although commercially available antiinflammatory drugs, such as non-steroidal anti-inflammatory drugs (NSAIDs), are effective in reducing inflammation, they have a wide range of side effects without definite impacts on chronic inflammation (3). Therefore, safer, and more efficient alternative complementary therapies are needed. Researchers found that plant extract effects

1: Department of Immunology \& Microbiology, School of Medicine, Arak University of Medical Sciences, Arak, Iran.

2: Traditional and Complementary Medicine Research Center (TCMRC), Department of Microbiology and Immunology, School of

Medicine, Arak University of Medical Sciences, Arak, Iran.

3: Molecular and Medicine Research Center, Department of Microbiology and Immunology, School of Medicine, Arak University of Medical Sciences, Arak, Iran.

*Corresponding author: Ghasem Mosayebi; Tel: +98863 4173502; E-mail: ghasemmosayebi@arakmu.ac.ir.

Received: 22 Feb, 2021; Accepted: 18 Apr, 2021 
were due to more than one component or fraction because the plant constituents had synergistic and interactive effects with each other. Thus, whole plant extracts, in addition to suppressing the undesirable effects of the major toxic constituents, increased efficiency and performance (1). In addition, because of the synergistic effect between plants, researchers have highlighted the concept of polyherbalism (4).

According to studies, both Silybum marianum (S. marianum), or milk thistle, and Nigella sativa ( $N$. sativa) have potent antioxidant and anti-inflammatory properties and have been used for years to treat of inflammatory disorders (5-7). Hence, this study aimed to investigate the attenuating effects of $S$. marianum methanolic extract (SME) and $N$. sativa ethanolic extract (NEE) on inflammation through macrophage polarization.

\section{Materials and Methods \\ Chemicals and reagents}

RPMI-1640 medium, fetal bovine serum (FBS), penicillin, streptomycin, dimethyl sulfoxide (DMSO), lipopolysaccharide (LPS), MTT (3-(4, 5-dimethyl-2-yl)-2, 5 diphenyl tetrazolium bromide), brewermodified thioglycollate, TPTZ $(2,4$, 6tripyridyl-s-triazine), and Griess reagent were provided by Sigma-Aldrich (Sigma, USA). Anti- CD4, CD25, and Foxp3 antibodies were supplied by eBioscience (eBioscience, USA). The total RNA Extraction Kit and the cDNA Synthesis Kit were purchased from Yekta Tajhiz (Yekta Tajhiz Azma, Iran). RAW 264.7 mouse macrophage cells were obtained from the Pasteur Institute (Tehran, Iran). Nhexane, methanol, and ethanol were purchased from Merck Company (Merck, Germany).

\section{Preparation of the herbal extracts}

$S$. marianum and $N$. sativa seeds were purchased from Tehran University of Medical Sciences. Dried $S$. marianum (30 g) was extracted in a Soxhlet system using n-hexane
$(75 \mathrm{~mL} ; 6 \mathrm{~h})$ and methanol $(75 \mathrm{~mL} ; 5 \mathrm{~h})$ as the solvents. Powdered N. sativa seeds $(60 \mathrm{~g})$ were extracted with $95 \%$ ethanol $\left(350 \mathrm{~mL} ; 78{ }^{\circ} \mathrm{C} ; 8\right.$ h). The extracts were filtered, the solvent was removed under vacuum in a rotary evaporator, and the residue was evaporated at $37^{\circ} \mathrm{C}$ in an incubator $(8,9)$.

\section{In vitro study on $R A W 264.7$ cells Cell viability assay}

RAW 264.7 cells were cultured at a density of $2 \times 10^{4}$ cells/well in a 96-well culture plate in complete RPMI-1640 supplemented with $10 \%$ FBS, $100 \mathrm{U} / \mathrm{mL}$ penicillin, and $100 \mu \mathrm{g} / \mathrm{mL}$ streptomycin in $5 \% \mathrm{CO} 2$ at $37{ }^{\circ} \mathrm{C}$. Then, the cultured cells were treated with $50-800$ $\mu \mathrm{g} / \mathrm{mL}$ of SME, NEE, or the SME+NEE mixture, all in triplicate. After $4 \mathrm{hr}$ of incubation, the cells were stimulated with LPS $(1 \mu \mathrm{g} / \mathrm{mL})$ for $24 \mathrm{hr}$. Finally, $10 \mu \mathrm{L}$ of $5 \mathrm{mg} / \mathrm{mL}$ MTT was added to each well and the cells were incubated for an additional $4 \mathrm{hr}$. Subsequently, $100 \mu \mathrm{L} /$ well of DMSO was added to each well and mixed for $30 \mathrm{~min}$ in the dark. Then, the optical density (OD) was measured at $570 \mathrm{~nm}$ on a microplate reader (Stat Fax 2100, USA) (10).

\section{Nitric oxide determination}

Nitric oxide was measured by the Griess reaction $(11,12)$. Briefly, RAW 246.7 cells were seeded in a 96 -well culture plate at $2 \times 10^{4}$ cells/well, incubated overnight, and then treated with $50-800 \mu \mathrm{g} / \mathrm{mL}$ of the SME, NEE and SME+NEE extracts. Dexamethasone was used at a concentration of $1 \mu \mathrm{M} / \mathrm{mL}$ as a positive control (13). After $4 \mathrm{hr}$ of incubation, the treated cells were stimulated with LPS (1 $\mu \mathrm{g} / \mathrm{mL}$ ) and again incubated for 24 hours. Finally, the cell supernatants were collected, and their NO levels were measured by the Griess method.

\section{Cytokine gene expression assay}

Briefly, RAW 264.7 cells were seeded in a 24well culture plate at $1 \times 10^{5}$ cells/well. After overnight incubation, the macrophages were treated with $200 \mu \mathrm{g} / \mathrm{mL}$ of SME, $800 \mu \mathrm{g} / \mathrm{mL}$ of 
NEE and $400 \mu \mathrm{g} / \mathrm{mL}$ of SME+NEE extracts. After $4 \mathrm{hr}$, the treated cells were stimulated with LPS $(1 \mu \mathrm{g} / \mathrm{mL})$ and incubated for $24 \mathrm{hr}$. The cells were harvested, total RNA was extracted, and cDNA was synthesized according to the manufacturer's instructions. Forward and reverse primers of the target genes (IL-10, IL-6, TGF- $\beta$, and TNF- $\alpha$ ) and a housekeeping gene (GAPDH) were designed using Allele ID 6 software (Premier Bio soft, USA) and aligned in BLAST web sites (Table 1). Real-time PCRs were run in duplicate using
SYBR Green I 2x Master Mix (Yekta Tajhiz, Iran) on a Roche light cycler ${ }^{\circledR} 96$ (Roche, Switzerland). PCR products for each mRNA were verified by the melting curve assay. Also, 2\% agarose gel electrophoresis was used to assess potential primer-dimer formation and non-specific product amplification for the data analysis. The Pfaffle method was used to calculate the relative gene expression. The ratios were considered as the final results for statistical analysis.

Table 1. PCR Primer Sequences.

\begin{tabular}{llll}
\hline Target & Amplicon $(\mathbf{b p})$ & Primers & Sequences, $\mathbf{5}^{\prime} \rightarrow \mathbf{3}$ \\
\hline GAPDH & 224 & $\mathrm{~F}$ & CGGTGTGAACGGATTTGG \\
& & $\mathrm{R}$ & CTCGCTCCTGGAAGATGG \\
\hline IL-6 & 157 & $\mathrm{~F}$ & GAAATGATGGATGCTACCAAACTG \\
\hline TGF- $\boldsymbol{\beta}$ & 193 & $\mathrm{R}$ & TCTGTATCTCTCTGAAGGACTCTG \\
\hline TNF- $\boldsymbol{\alpha}$ & 201 & $\mathrm{~F}$ & AATTCCTGGCGTTACCTTGG \\
& & $\mathrm{R}$ & GGCTGATCCCGTTGATTTCC \\
\hline \multirow{2}{*}{$\mathbf{I L - 1 0}$} & 224 & $\mathrm{~F}$ & CCTCTTCTCATTCCTGCTTGTG \\
& & $\mathrm{R}$ & ACTTGGTGGTTTGCTACGAC \\
\hline
\end{tabular}

GAPDH: glyceraldehyde-3-phosphate dehydrogenase; TGF- $\beta$ : transforming growth factor- $\beta$; TNF- $\alpha$ : Tumor necrosis factor-alpha; IL: interleukin; F: Forward; R: Reverse.

\section{In vivo study on peritoneal macrophages Mice treatment}

Experiments were performed using male BALB/c mice (18-22 g) obtained from the Pasteur Institute of Iran. The SME and NEE extracts were gavaged at $2000 \mathrm{mg} / \mathrm{kg}$ daily for 14 days according to the previous studies (14, 15). Another group was gavaged with the SME+NEE combination at a 50/50 ratio. The control group received $30 \%$ DMSO as a vehicle (16). The positive control group received dexamethasone intraperitoneally at $0.15 \mathrm{mg} / \mathrm{kg}(17)$.

\section{Acute toxicity of the extracts}

The acute toxicity test was performed based on the Organization for Economic Co-operation and Development guidelines. According to these guidelines the mice weights were measured every three days for 14 days (18). Moreover, the extracts' toxicities on splenocytes were evaluated by MTT assay.

\section{Thioglycollate-induced peritonitis model}

On the $10^{\text {th }}$ day of treatment, four days before the last gavage, peritoneal inflammation was induced by intraperitoneal injection of $1 \mathrm{~mL}$ of 
a sterile solution of Brewer-modified thioglycollate medium (3\% w/v in PBS) (19). Peritoneal macrophages were collected by lavaging the peritoneal cavity with $10 \mathrm{~mL}$ of harvest medium (EDTA 5mM + PBS) (20). Isolated peritoneal exudate cells were washed twice with RPMI and centrifuged at $400 \times \mathrm{G}$ for $10 \mathrm{~min}$ at $4{ }^{\circ} \mathrm{C}$. Finally, the cell suspension was dispensed in complete RPMI-1640 and allowed to adhere to the bottom of the $6 \mathrm{~cm}$ culture plate at $37{ }^{\circ} \mathrm{C}$ for $4 \mathrm{hr}$ in $5 \% \mathrm{CO}_{2}$. The plates were then washed with warm PBS to remove non-adherent cells. The attached cells were considered as macrophages with $90 \%$ purity (20).

\section{NO determination and cytokine gene expression}

The scraped peritoneal macrophages at $2 \times 10^{4}$ cells/well were incubated overnight in a 24 well culture plate with $1 \mu \mathrm{g} / \mathrm{mL}$ of LPS for 24 $\mathrm{h}$ for the NO assay and cytokine gene expression. The NO assay, total RNA extraction, cDNA synthesis, and real-time PCR were performed as described in sections 2.3.2 and 2.3.3.

Flow cytometry analysis of splenic Treg cells The euthanized mice spleens were excised under sterile conditions, and single-cell suspensions isolated by perfusion with FACS buffer. After RBC removal with lysis solution $\left(0.5 \mathrm{M} \mathrm{NH}_{4} \mathrm{Cl}, 10 \mathrm{mM} \mathrm{KHCO}_{3}\right.$, and $0.1 \mathrm{mM}$ disodium EDTA, $\mathrm{pH}$ 7.2), flow cytometry analysis was performed using a BD FACSCalibur (BD Biosciences, CA, USA). For this purpose, peridinin chlorophyll protein complex (PerCP)-labeled anti-mouse CD25 and PE-labeled anti-mouse CD4, and FITClabeled anti-mouse forkhead box P3 (FoxP3) were used. All the experiments were performed according to the manufacturer's instructions. Acquisition and analysis were erformed with Flowjo software (Tree Star,
Inc., OR, USA) by counting 10000 cells.

\section{Statistical Analysis}

Statistical tests were performed using the SPSS software version 16.0 (SPSS, Inc., Chicago, IL, USA). The ANOVA method was used to evaluate differences between variables in each of the studied groups. The means between groups were compared by the post hoc Tukey test. $\mathrm{P}$ values less than 0.05 were considered significant. Data were expressed as means \pm standard errors of the means. All graphs were made using GraphPad Prism software version 6.07 .

\section{Results \\ Cytotoxicity of the extracts on RAW264.7 macrophages}

Viabilities of cells treated with the NEE, SME, or SME+NEE extracts at all concentrations, either without or with LPS at $1 \mu \mathrm{g} / \mathrm{mL}$ were not significantly different from the controls (Figs. $1 \mathrm{~A}$ and $1 \mathrm{~B}$, respectively).

\section{Nitric oxide production in RAW264.7 macrophages}

Nitric oxide concentrations were significantly greater in the LPS - $(1 \mu \mathrm{g} / \mathrm{mL})$ stimulated than in the non-LPS-stimulated cells $(p=0.001)$ (Figs. 2A-C). Treatment of LPS-stimulated macrophages with $200-800 \mu \mathrm{g} / \mathrm{mL}$ SME resulted in a significantly less NO than in the control $(p=0.01)$ (Fig. 2A). Also, LPSinduced NO production was significantly less than control in NEE group at concentrations of 400,600 , and $800 \mu \mathrm{g} / \mathrm{mL}$ ( $\mathrm{p}=0.038,0.040$, and 0.004 , respectively) (Fig. 2B). Nitric oxide production was also significantly less than control following incubation with the SME+NEE extract at 400, 600, and 800 $\mu \mathrm{g} / \mathrm{mL} \quad(\mathrm{p}=0.038, \quad 0.018$, and 0.015, respectively) (Fig. 2C). 

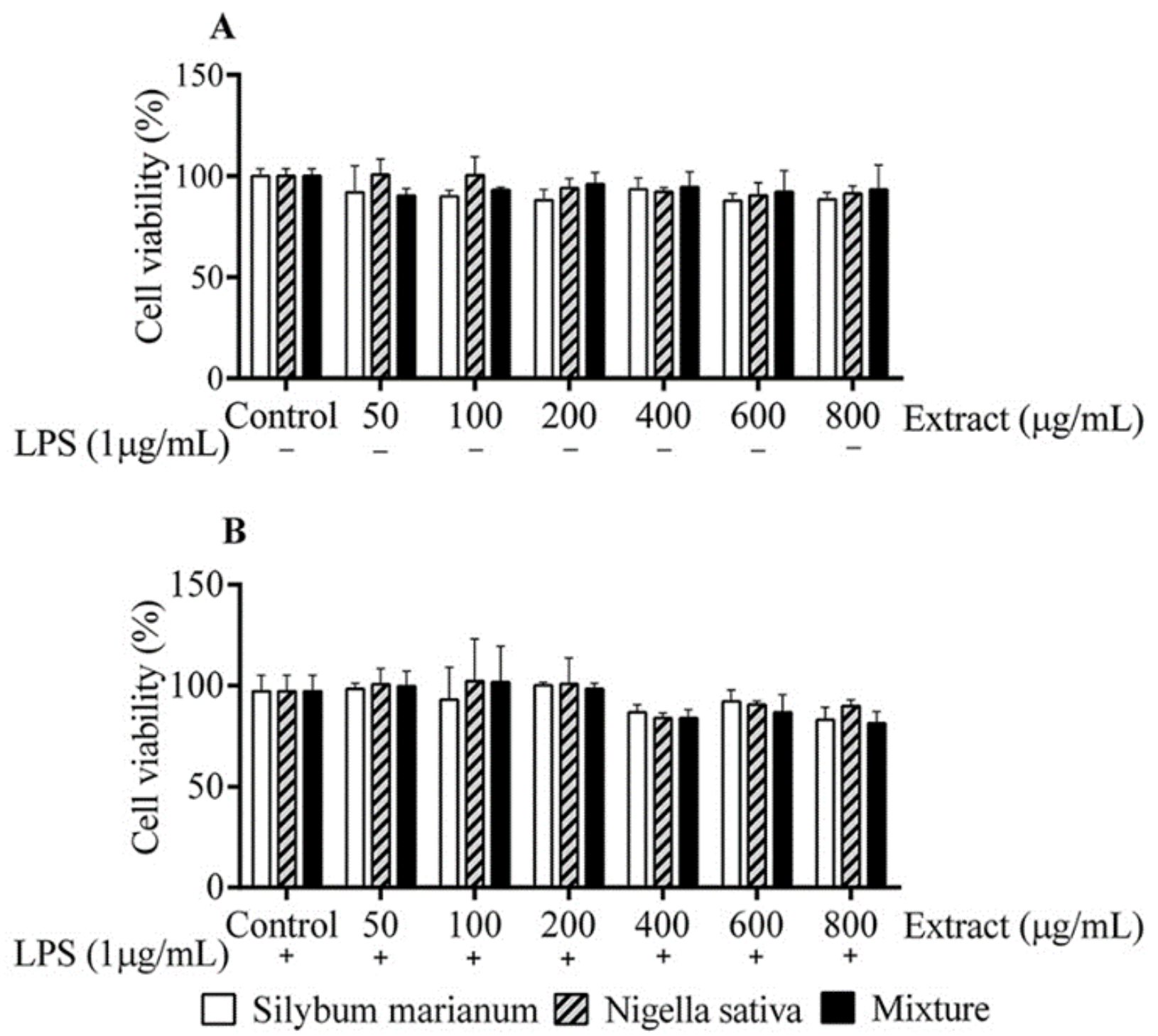

Fig. 1. Effects of NEE (N. sativa), SME (S. marianum), and SME+NEE (Mixture) on cell viability. Cell viability was evaluated by MTT assay 24 hours after treatment (A) without LPS, (B) with LPS (1 $\mu \mathrm{g} / \mathrm{mL})$ in RAW264.7 macrophage cells. Values are the means \pm SEMs of three independent experiments. LPS: lipopolysaccharide. 
A

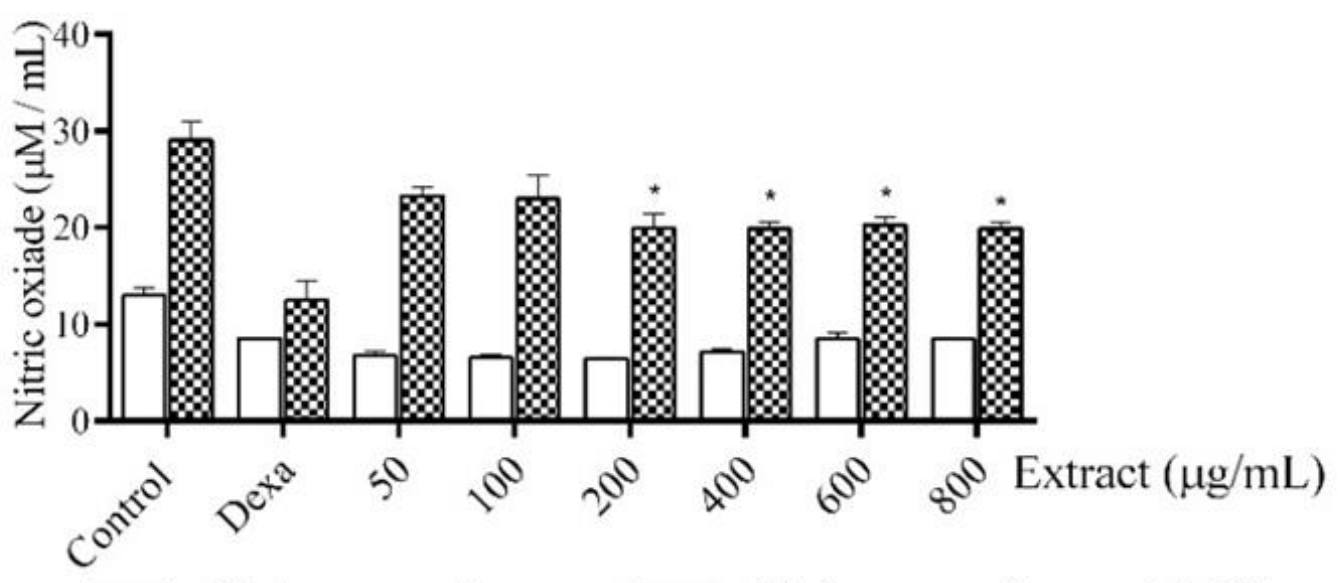

B $\square$ Siybum marianum $\boldsymbol{m}$ Siybum marianum+ LPS

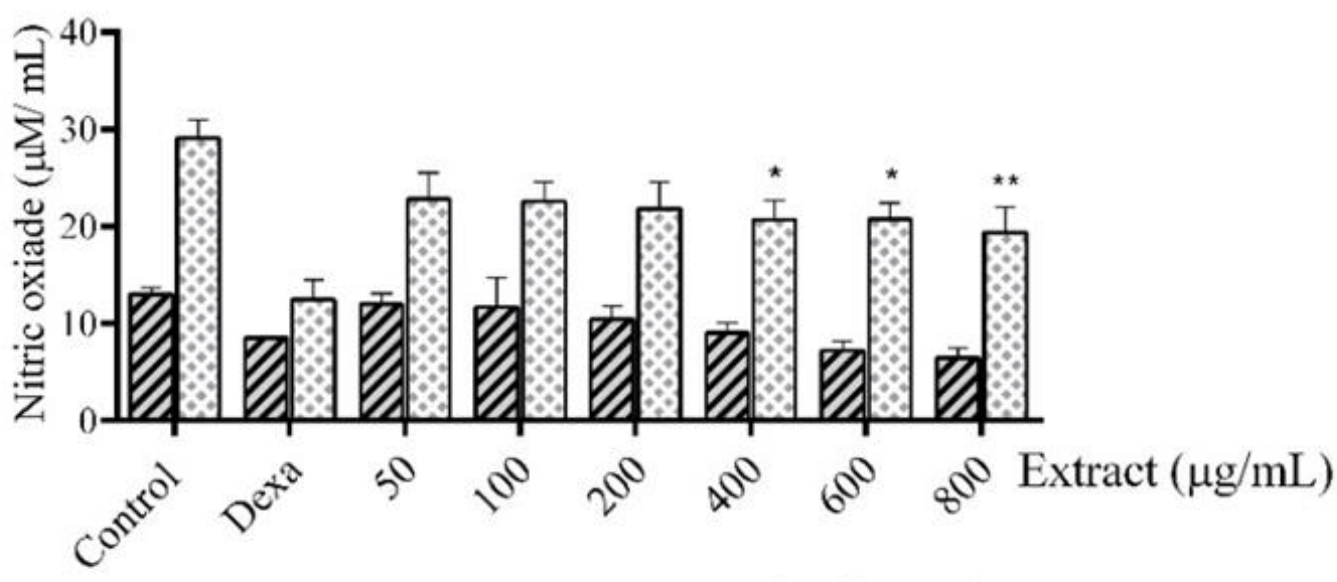

C Nigella sativa $\square$ Nigella sativa+ LPS

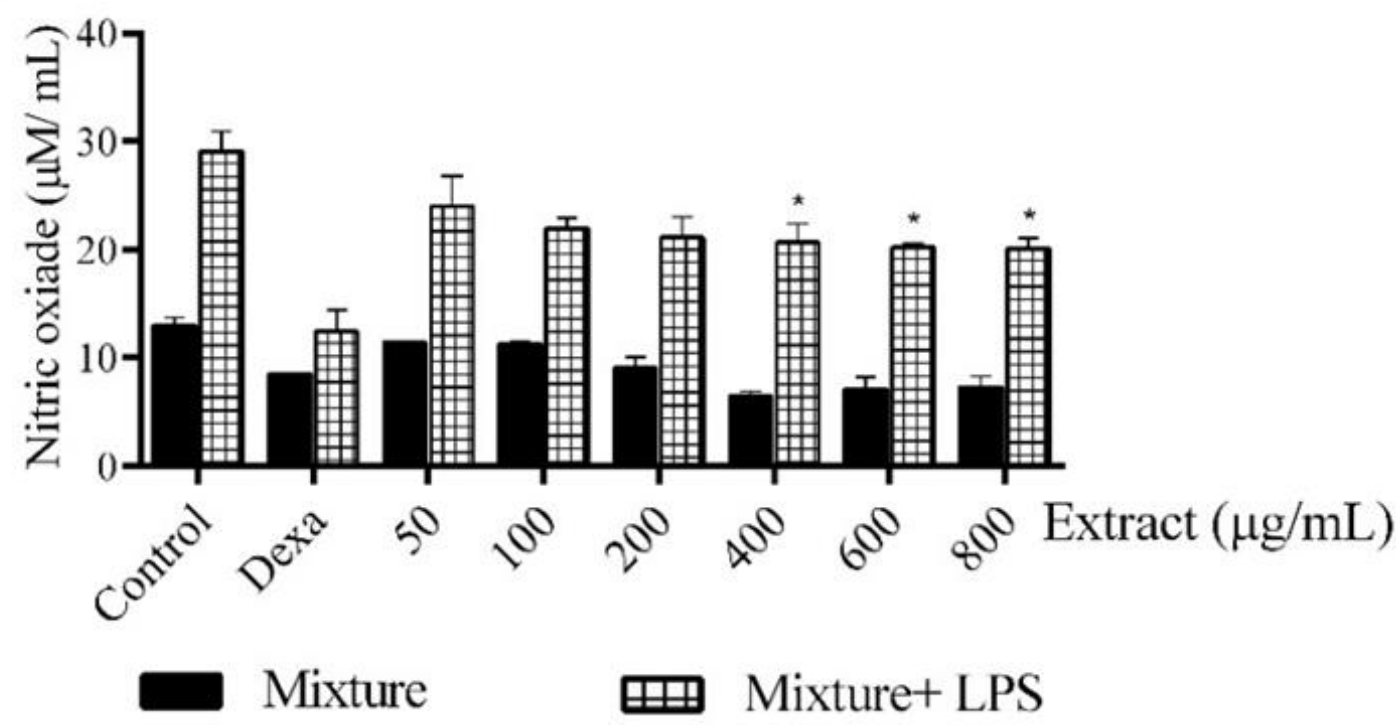

Fig. 2. Effects of (A) SME (S. marianum), (B) NEE (N. sativa), and (C) SME+NEE (Mixture) at various concentrations on NO production in RAW 264.7 macrophages with and without LPS. The data are representative of three experiments and expressed as means \pm SEMs. $* \mathrm{p}<0.05 * \mathrm{*} p<0.01$ versus control. 
Cytokine gene expression in RAW264.7 macrophages

IL-10 gene expression was significantly greater in RAW 264.7 cells treated with $800 \mu \mathrm{g} / \mathrm{mL}$ of NEE than in controls ( $p=0.0001$, Fig. 3A). Also, NEE-treated cells expressed significantly less TGF- $\beta$, TNF- $\alpha$, and IL- 6 than control cells ( $\mathrm{p}=$ $0.012,0.001$, and 0.0015, Figs. 3B, 3C, and 3D, respectively). IL-10, TGF- $\beta$, TNF- $\alpha$, and IL-6 gene expression in RAW 264.7 cells was not significantly different between those treated with $200 \mu \mathrm{g} / \mathrm{mL}$ of SME and $400 \mu \mathrm{g} / \mathrm{mL}$ of SME+NEE extracts and controls (Figs 3A3D).
A $\quad$ IL-10

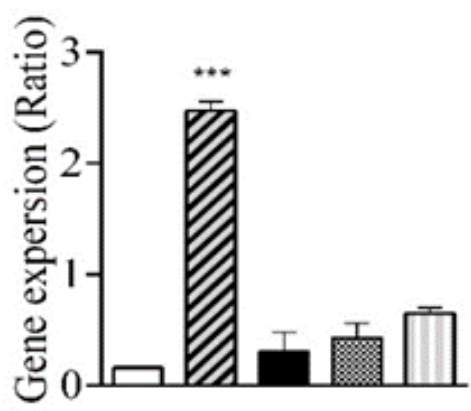

C

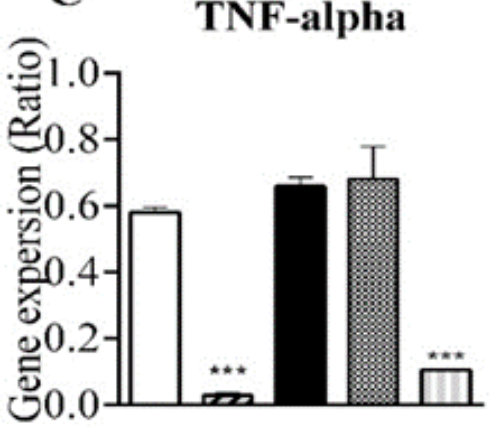

B
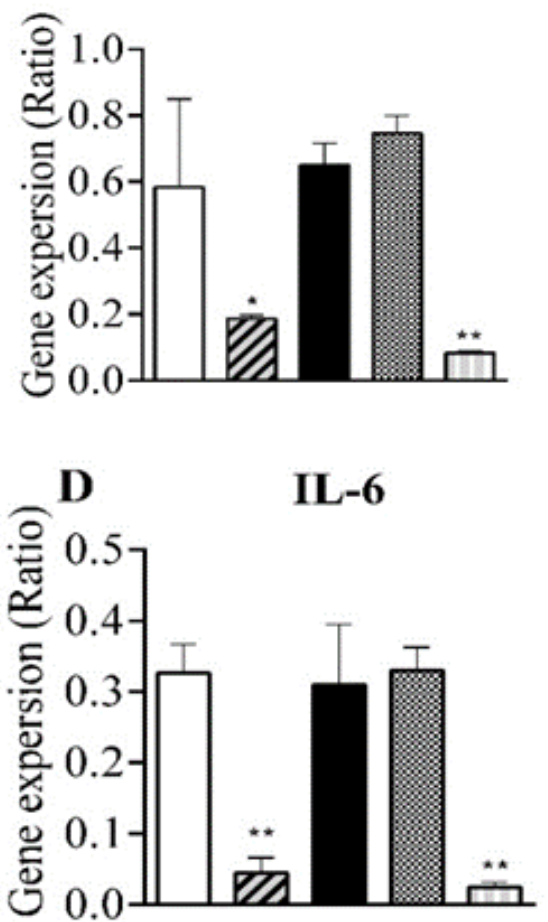

\section{Silybum marianum $\mathbb{Z}$ Nigella sativa $\square$ Mixture $\square$ Dexa Control}

Fig. 3. The effects of SME (S. marianum) $(200 \mu \mathrm{g} / \mathrm{mL})$, NEE ( $N$. sativa) $(800 \mu \mathrm{g} / \mathrm{mL})$, and SME+NEE (Mixture) (400 $\mu \mathrm{g} / \mathrm{mL}$ ), on (A) IL-10, (B) TGF- $\beta$, (C) TNF- $\alpha$, and (D) IL-6 expression in RAW 264.7 cells. The controls cells were treated with DMSO+LPS. Data represent means \pm SEMs of duplicate independent experiments. $* \mathrm{p}<0.05, * * \mathrm{p}<0.01$, $* * * p<0.001$ versus DMSO control.

\section{Acute toxicity of the extracts on the animal model}

Mice weights did not differ between those treated with the extracts and controls, indicating the non-toxic nature of extracts at the tested dosage (Fig. 4A). In confirmation of the non-toxicity of these extracts, spleen lymphocytes viability from treated mice was not significantly different from control (Fig. 4B). 


\section{A}

$\rightarrow$ Silybum marianum $\rightarrow$ Nigella sativa

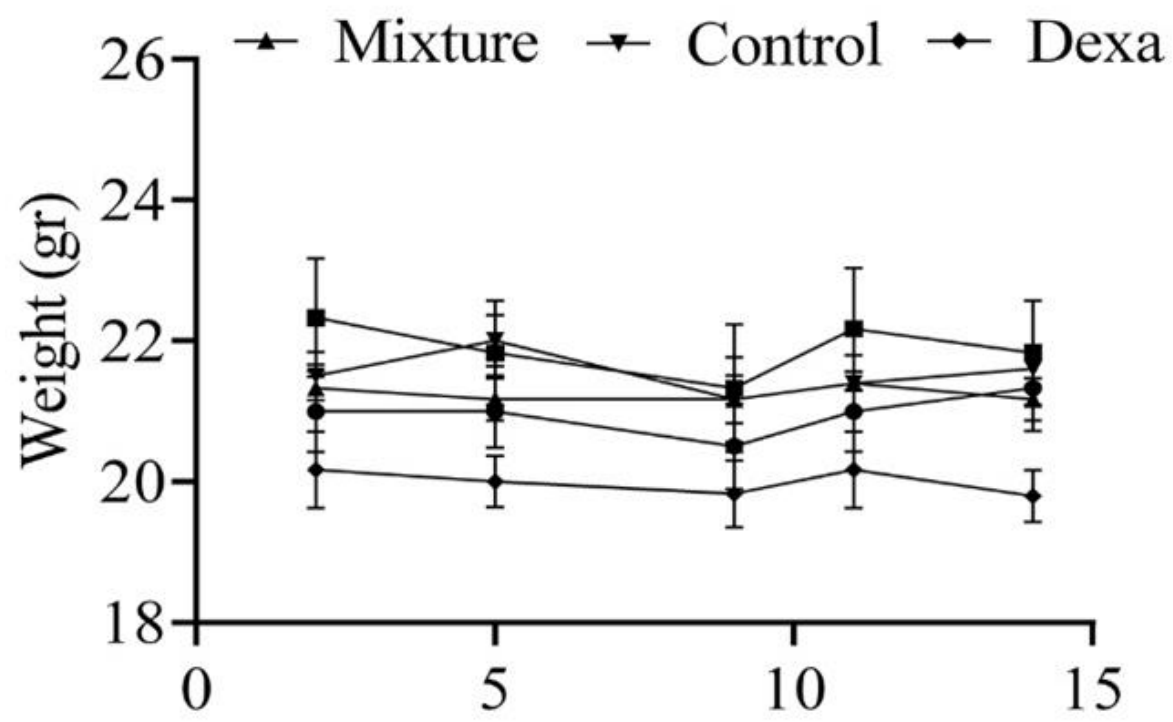

B

Day

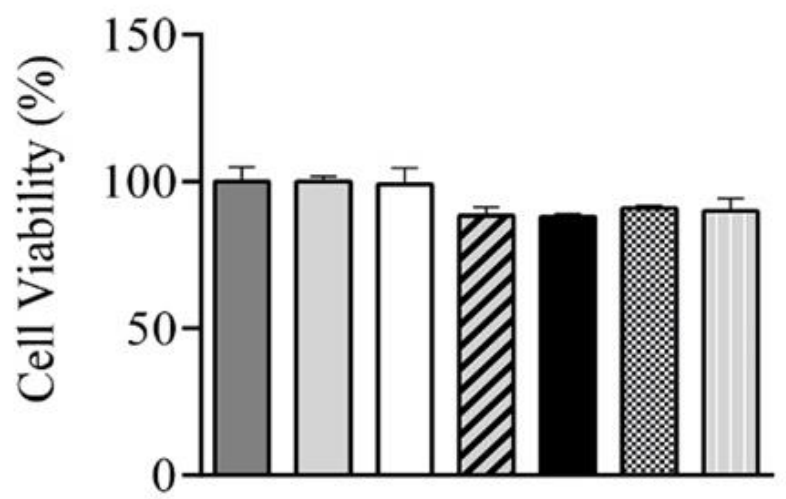

$\operatorname{LPS}(1 \mu \mathrm{g} / \mathrm{mL})-++++++$

\section{Cell $\square$ Cell + LPS $\gg$ Control $\square$ Dexa}

\section{Silybum marianum $\mathbb{Z}$ Nigella sativa $\square$ Mixture}

Fig. 4. Effects of SEM (S. marianum), NEE (N. sativa) and SME+NEE (Mixture) on mice body weights and splenocyte viability. (A) Weights of treated groups (B) Spleen lymphocyte viability. Viability was determined by MTT assay. Values are the means \pm SEMs of three independent experiments. Cell: group that received no treatment, control: group were treated with 30\% DMSO for 14 days as solvent for extract.

\section{NO production in LPS-stimulated peritoneal macrophages}

Nitric oxide concentrations in the supernatants of peritoneal macrophages treated with SME, NEE, SME+NEE, and dexamethasone $(0.15 \mathrm{mg} / \mathrm{kg}) \quad$ were all significantly less than in the control $(\mathrm{p}=0.001$, Fig. 5). 


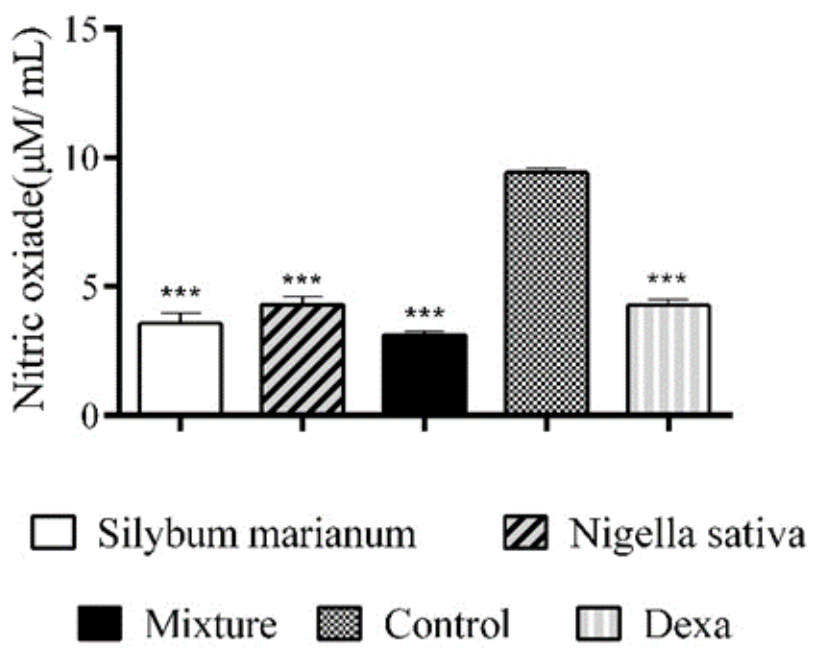

Fig. 5. Effect of SEM (S. marianum), NEE (N. sativa) and SME+NEE (Mixture) on NO production in the supernatants of cultured peritoneal macrophages from mice with thioglycollate-induced peritonitis. The data are expressed as means \pm SEMs. $* * * \mathrm{p}<0.001$ versus DMSO control.

\section{Gene expression in LPS-stimulated peritoneal macrophages}

IL-10 and TGF- $\beta$ expression were significantly greater in the SME+NEE-treated cells than in the control cells ( $p=0.0045$ and 0.037 , Figs. $6 \mathrm{~A}$ and $6 \mathrm{~B}$, respectively), while TNF- $\alpha$ and IL-6 expression were significantly less than control $(\mathrm{p}=0.034$ and 0.010 , Figs. 6C and 6D, respectively). IL-6 expression in NEE extract and LPS-stimulated peritoneal macrophages was significantly less than control $(p=0.026$, Fig. 6D).
A

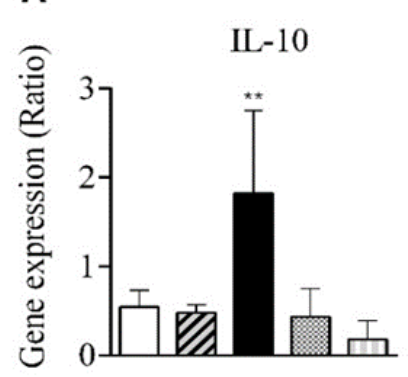

C

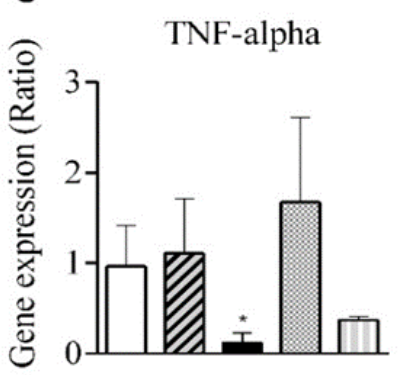

B
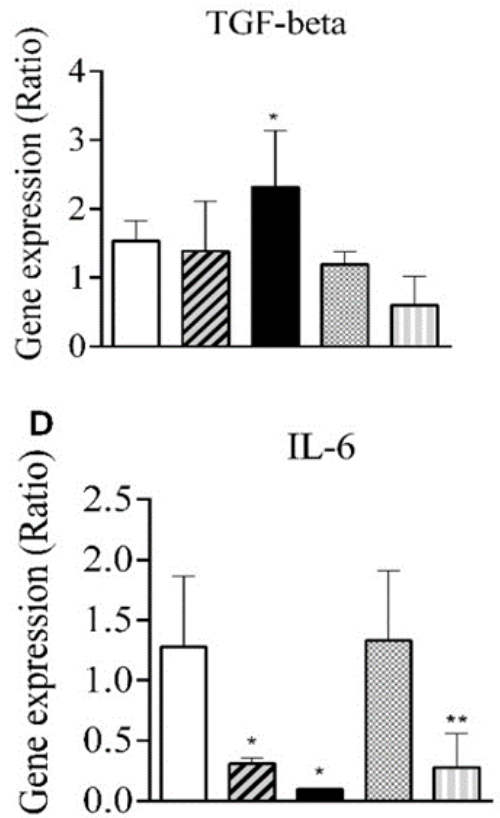

Silybum marianum

$\mathbb{Z}$ Nigella sativa

Mixture

Dexa

Control

Fig. 6. The effects of SEM (S. marianum), NEE ( N. sativa) and SME+NEE (Mixture) on (A) IL-10, (B) TGF- $\beta$, (C) TNF- $\alpha$, and (D) IL-6 expression in LPS-stimulated macrophages. Data represent means \pm SEMs of duplicate independent experiments. $* \mathrm{p}<0.05, * * \mathrm{p}<0.01$ versus DMSO control. 


\section{Effect of herbal extracts on splenic Treg cells}

Regulatory $\mathrm{T}$ cells were analyzed by flow cytometry, in which firstly lymphocytes were isolated through forward and side scatter characteristics (Fig. 7A). Then separated CD4+ $\mathrm{T}$ lymphocytes were separated based on CD4 marker (Fig. 7B), and finally, Treg cells were reported based on the proportion of FoxP3+, $\mathrm{CD} 25+$ markers in the population of CD4+ $\mathrm{T}$ cells (Fig. 7C). The percentage of Treg cells was more significant in the $\mathrm{SME}+\mathrm{NEE}$ treatment group than in those treated with the other extracts or controls $(p=0.015$, Fig. 7D).
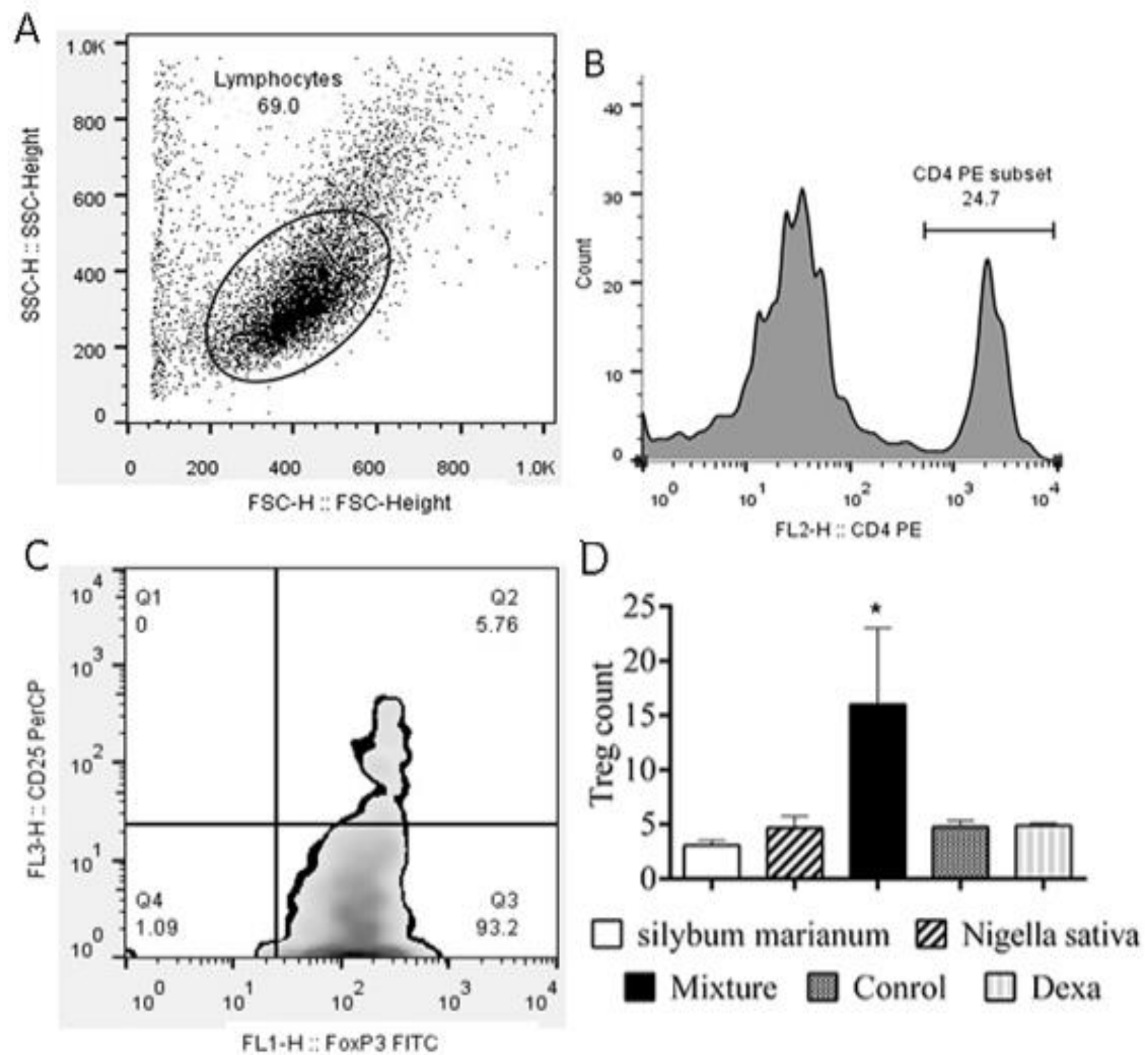

Fig. 7. Results of flow cytometry measurement and gating strategy. (A) Identification of cellular subsets based on forward and side scatter characteristics. (B) The histogram shows the count of separated lymphocytes based on the CD4 marker. (C) The percentage of FoxP3+, CD25+ T cells in CD4+ T cells population which was stained with PerCP and FITC fluorochromes (D) Effect of SEM (S. marianum), NEE ( . sativa), and SME+NEE (Mixture) on splenic T-reg cell number $(* \mathrm{p}<0.05)$.

\section{Discussion}

According to our result a mixture of SME+NEE has anti-inflammatory and immunomodulatory activities without cytotoxic effects on inflammatory macrophages. Our findings agree with a study that showed classical macrophages play key roles in inflammation by producing 
inflammatory mediators such as nitrite oxide and inflammatory cytokines (21). Previous evidence showed the anti-inflammatory and immunomodulatory properties of NEE and SME in rheumatoid arthritis, preeclampsia, asthma, and respiratory diseases $(5,22)$. In this study, we investigated the synergistic effects of NEE and SME extracts and their mixture on immunomodulation of inflammatory macrophages in vitro and in vivo.

The extracts had no toxic effects on RAW264.7 cells or splenic lymphocytes either in the presence or absence of LPS. Acute toxicity results also demonstrated their safety at the doses administered to mice. Therefore, the inhibitory effects of these extracts on inflammatory macrophages were not due to toxic or cell-killing effects $(23,24)$. LPS is an important stimulus that leads to classical macrophage activation. The appropriate dose of LPS without apoptosis induction was chosen based on previous studies (1 $\mu \mathrm{g} / \mathrm{mL})(25,26)$. Cho et al. showed no cytotoxic effect of deoxysilybin from SME even at the relatively high concentration of $750 \mu \mathrm{g} / \mathrm{mL}$ on RAW264.7 cells (27). In parallel studies the hydroalcoholic extract of NEE and thymoquinone had no cytotoxic effects at concentrations greater than that used in our study $(28,29)$. Extensive in vivo studies have shown a lack of acute and chronic toxicity of SME and NEE extracts on laboratory animals even at high doses $(30,31)$.

Our results also indicated that the extracts significantly inhibited LPS-induced NO production in a concentration-dependent manner on RAW264.7 cells and peritoneal macrophages. Moreover, the inhibitory function of the mixture was stronger than the dexamethasone, which confirmed their polyherbalism and synergistic effects. In line with our study, thymoquinone showed an anti-inflammatory effect by inhibiting $\mathrm{NF}-\kappa \mathrm{B}$ signaling and iNOS mRNA expression in RAW264.7 macrophages (32). In contrast, thymoquinone increased NO levels and induced inflammatory macrophages (33). This discrepancy might be due to the responsiveness of the different cell lines.
According to studies, silibinin from SME has been reported to inhibit NO production by blocking iNOS expression and blocking the P38, MAPK, and NF- $\mathrm{KB}$ signaling pathways, thus inhibiting the activity of stimulated mouse peritoneal macrophages and RAW 264.7 cells (34-36). In vivo studies confirmed the results of this study; aqueous NEE extract on peritoneal macrophages stimulated with LPS and IFN- $\gamma$ suppressed NO production (24). In parallel, carvacrol, from NEE extract, significantly decreased serum NO in patients with respiratory inflammation (37). Therefore, the antiinflammatory effect of NEE in the present study was likely due to the combined activity of multiple components in the extract mixture.

In this study, SME extract had no significant effect on inflammatory gene expression in RAW264.7 and peritoneal macrophages; however, in agreement with previous studies, NEE extract inhibited proinflammatory cytokine production. In this regard, the aqueous NEE extract and thymoquinone suppressed TNF- $\alpha$ and IL-6 in peritoneal macrophages stimulated by LPS and IFN- $\gamma$ (24) and TNF- $\alpha$ in RAW264.7 mouse macrophages stimulated by LPS $(24,32)$. Others have observed an ethanolic extract of NEE decreased IL-6 expression in macrophages derived from human monocytes (9). El-Dakhakhny et al. reported that NEE oil has a greater inhibitory effect than thymoquinone on the inflammatory cascade. Hence, it is likely that oil components may also be involved in the extracts in our study $(38,39)$.

In the present study, SME had no significant effect on IL-10 and TGF- $\beta$ expression in RAW264.7 and peritoneal macrophages, whereas a significant increase in IL-10 was observed in NEE-treated RAW264.7 macrophages. In this regard, evidence has shown that thymoquinone in NEE increases IL-10 production in RAW264.7 and peritoneal macrophages through attenuation of the NF- $\mathrm{kB}$ signaling pathway $(40,41)$. The current study demonstrated that the combination of the two extracts significantly increased IL-10 and TGF$\beta$, and decreased TNF- $\alpha$ and IL- 6 expression. This finding indicates the combined synergistic effect of these two plants in vivo. 
One valuable property of both NEE and SME is their regulatory effect on the immune system. We observed a significant increase in the number of splenic regulatory lymphocytes in the combination group. In contrast, silymarin and NEE extract increased Treg cell numbers in rats exposed to gamma-rays and ovalbumin, respectively. This discrepancy might be due to the lower concentration of the extracts that we used (42).

In conclusion, the LPS-activated mouse macrophage cell model is an economic approach for basic screening of the extracts' antiinflammatory activity. Our results demonstrated a combination of SME+NEE may prevent inflammation. Future studies will be directed towards clarifying the signaling pathways inhibited by the combined extracts.

\section{References}

1. Hashiguchi A, Hitachi K, Zhu W, Tian J, Tsuchida K, Komatsu S. Mung bean (Vigna radiata (L.)) coat extract modulates macrophage functions to enhance antigen presentation: A proteomic study. J Proteomics. 2017;161:26-37.

2. Kumar V, Abbas AK, Fausto N, Aster JC. Robbins and Cotran pathologic basis of disease. elsevier health sciences; 2014.

3. Ajayi AM, de Oliveira Martins DT, Balogun SO, de Oliveira RG, Ascêncio SD, Soares IM, et al. Ocimum gratissimum L. leaf flavonoid-rich fraction suppress LPS-induced inflammatory response in RAW 264.7 macrophages and peritonitis in mice. Journal of ethnopharmacology. 2017;204:169-178.

4. Parasuraman S, Thing GS, Dhanaraj SA. Polyherbal formulation: Concept of ayurveda. Pharmacogn Rev. 2014;8(16):73-80.

5. Esmaeil N, Anaraki SB, Gharagozloo M, Moayedi B. Silymarin impacts on immune system as an immunomodulator: One key for many locks. Int Immunopharmacol. 2017;50:194-201.

6. El Mezayen R, El Gazzar M, Nicolls MR, Marecki JC, Dreskin SC, Nomiyama H. Effect of thymoquinone on cyclooxygenase expression and prostaglandin production in a mouse model of
These results suggest that the SME+NEE mixture has anti-inflammatory and immunomodulatory activity, and thus, may be of value in the treatment of diseases of immunopathological origin characterized by macrophage hyperactivation.

\section{Acknowledgements}

This article is taken from the Master thesis with code 3196. the authors thank the Deputy for Research and Technology of Arak University of Medical Sciences for their valuable support.

This study was sponsored by the Deputy for Research and Technology of Arak University of the Medical Sciences.

The authors hereby state that there are no conflicts of interest in the present research.

allergic airway inflammation. Immunol Lett. 2006;106(1):72-81.

7. Salem ML. Immunomodulatory and therapeutic properties of the Nigella sativa $L$. seed. Int Immunopharmacol. 2005;5(1314):1749-70.

8. Wianowska D, Wiśniewski M. Simplified procedure of silymarin extraction from Silybum marianum L. Gaertner. Journal of chromatographic science. 2014;53(2):366-72.

9. Koshak AE, Yousif NM, Fiebich BL, Koshak EA, Heinrich MJFiP. Comparative Immunomodulatory Activity of Nigella sativa L. Preparations on Proinflammatory Mediators: A Focus on Asthma. 2018;9:1075.

10. Patel S, Gheewala N, Suthar A, Shah A. Invitro cytotoxicity activity of Solanum nigrum extract against Hela cell line and Vero cell line. International journal of pharmacy and pharmaceutical sciences. 2009;1(1):38-46.

11. Green LC, Wagner DA, Glogowski J, Skipper PL, Wishnok JS, Tannenbaum SR. Analysis of nitrate, nitrite, and $[15 \mathrm{~N}]$ nitrate in biological fluids. Anal Biochem. 1982;126(1):131-8.

12. Jalalvand M, Shahsavari G, Mosayebi G. The Inhibitory Effect of Satureja khozestanica Essential Oil and Carvacrol on Nitric Oxide 
Production in Macrophage Cell Line. 2014;16(3):31-46.

13. Li Q, Dong D-D, Huang Q-P, Li J, Du Y-Y, $\mathrm{Li} \mathrm{B}$, et al. The anti-inflammatory effect of Sonchus oleraceus aqueous extract on lipopolysaccharide stimulated RAW 264.7 cells and mice. 2017;55(1):799-809.

14. Soufy NI. Hepatoprotective and antioxidant effects of Silybum marianum plant against hepatotoxicity induced by carbon tetrachloride in rats. Journal of American Science. 2012;8(4):479-86.

15. Vahdati-Mashhadian N, Rakhshandeh $\mathrm{H}$, Omidi A. An investigation on LD50 and subacute hepatic toxicity of Nigella sativa seed extracts in mice. Pharmazie. 2005;60(7):544-7.

16. Noel PR, Barnett KC, Davies RE, Jolly DW, Leahy JS, Mawdesley-Thomas LE, et al. The toxicity of dimethyl sulphoxide (DMSO) for the dog, pig, rat and rabbit. Toxicology. 1975;3(2):143-69.

17. Xu T, Qiao J, Zhao L, He G, Li K, Wang J, et al. Effect of dexamethasone on acute respiratory distress syndrome induced by the H5N1 virus in mice. Eur Respir J. 2009;33(4):852-60.

18.OECD (2002), Test No. 423: Acute Oral toxicity- Acute Toxic Class Method, OECD Guidelines for the Testing of Chemicals, Section 4, OECD Publishing, Paris, https://doi.org/10.1787/9789264071001-en.

19. Lam D, Harris D, Qin Z. Inflammatory mediator profiling reveals immune properties of chemotactic gradients and macrophage mediator production inhibition during thioglycollate elicited peritoneal inflammation. Mediators Inflamm. 2013;2013:931562.

20. Zhang X, Gonçalves R, Mosser DM. The isolation and characterization of murine macrophages. Curr Protoc Immunol. 2008; chapter 14:Unit 14.1.

21. Larsen GL, Henson PM. Mediators of inflammation. Annual review of immunology. 1983;1:335-59.

22. Gholamnezhad Z, Keyhanmanesh R, Boskabady MH. Anti-inflammatory, antioxidant, and immunomodulatory aspects of Nigella sativa for its preventive and bronchodilatory effects on obstructive respiratory diseases: A review of basic and clinical evidence. Journal of Functional Foods. 2015;17:910-927.
23. Gharagozloo M, Jafari S, Esmaeil N, Javid EN, Bagherpour B, Rezaei A. Immunosuppressive Effect of Silymarin on Mitogen-Activated Protein Kinase Signalling Pathway: the Impact on T Cell Proliferation and Cytokine Production. Basic Clin Pharmacol Toxicol. 2013;113(3):209-14.

24. Majdalawieh AF, Hmaidan R, Carr RI. Nigella sativa modulates splenocyte proliferation, Th1/Th2 cytokine profile, macrophage function and NK anti-tumor activity. J Ethnopharmacol. 2010;131(2):268-75.

25. Liu Y, Su W-W, Wang S, Li P-B. Naringin inhibits chemokine production in an LPS-induced RAW 264.7 macrophage cell line. Mol Med Rep. 2012;6(6):1343-50.

26. Baatar D, Siddiqi MZ, Im WT, Ul Khaliq N, Hwang SG. Anti-inflammatory effect of ginsenoside $\mathrm{Rh} 2-\mathrm{mix}$ on lipopolysaccharidestimulated RAW 264.7 murine macrophage cells. J Med Food. 2018;21(10):951-960.

27. Cho BO, So Y, Jin CH, Nam BM, Yee S-T, Jeong IY. 3-deoxysilybin exerts antiinflammatory effects by suppressing NF- $\mathrm{BB}$ activation in lipopolysaccharide-stimulated RAW264. 7 macrophages. Biosci Biotechnol Biochem. 2014;78(12):2051-8.

28. Wilkins R, Tucci M, Benghuzzi $H$. The effects of egcg and tq on inflammatory mediator production in raw 264.7 cells challenged with LPS-biomed 2010. Biomed Sci Instrum. 2010;46:208-13.

29. Tabasi N, Mahmoudi M, Rastin M, Sadeghnia HR, HosseinPour Mashhadi M, Zamani Taghizade Rabe S, et al. Cytotoxic and apoptogenic properties of Nigella sativa and thymoquinone, its constituent, in human renal cell carcinoma are comparable with cisplatin. Food and agricultural immunology. 2015;26(1):138-56.

30. Bahmani M, Shirzad H, Rafieian S, RafieianKopaei M. Silybum marianum: beyond hepatoprotection. J Evid Based Complementary Altern Med. 2015;20(4):292-301.

31. Hajhashemi V, Ghannadi A, Jafarabadi H. Black cumin seed essential oil, as a potent analgesic and antiinflammatory drug. Phytother Res. 2004;18(3):195-9.

32.Hossen MJ, Yang WS, Kim D, Aravinthan A, Kim J-H, Cho JY. Thymoquinone: an IRAK1 
inhibitor with in vivo and in vitro antiinflammatory activities. Sci Rep. 2017;7:42995. 33. Miliani M, Nouar M, Paris O, Lefranc G, Mennechet F, Aribi M. Thymoquinone Potently Enhances the Activities of Classically Activated Macrophages Pulsed with Necrotic Jurkat Cell Lysates and the Production of Antitumor Th1-/M1-Related Cytokines. J Interferon Cytokine Res. 2018;38(12):539551.

34. Youn CK, Park SJ, Lee MY, Cha MJ, Kim OH, You HJ, et al. Silibinin inhibits LPSinduced macrophage activation by blocking p38 MAPK in RAW 264.7 cells. Biomol Ther (Seoul). 2013;21(4):258-263.

35. Kang JS, Jeon YJ, Kim HM, Han SH, Yang K-H. Inhibition of inducible nitricoxide synthase expression by silymarin in lipopolysaccharide-stimulated macrophages. J Pharmacol Exp Ther. 2002;302(1):138-44. 36. Tong $\mathrm{W}$, Zhang $\mathrm{C}$, Hong $\mathrm{T}$, Liu $\mathrm{D}$, Wang $\mathrm{C}$, $\mathrm{Li} \mathrm{J}$, et al. Silibinin alleviates inflammation and induces apoptosis in human rheumatoid arthritis fibroblast-like synoviocytes and has a therapeutic effect on arthritis in rats. Sci Rep. 2018;8:3241.
37. Boskabady MH, Jalali S. Effect of carvacrol on tracheal responsiveness, inflammatory mediators, total and differential WBC count in blood of sensitized guinea pigs. Exp Biol Med (Maywood). 2013;238(2):200-8.

38. El-Dakhakhny M, Madi N, Lembert N, Ammon H. Nigella sativa oil, nigellone and derived thymoquinone inhibit synthesis of 5lipoxygenase products in polymorphonuclear leukocytes from rats. J Ethnopharmacol. 2002;81(2):161-4.

39. Burits M, Bucar F. Antioxidant activity of Nigella sativa essential oil. Phytother Res. 2000;14(5):323-8.

40. Hussein MM, Ahmed MM. The Th1/Th2 paradigm in lambda cyhalothrin-induced spleen toxicity: the role of thymoquinone. Environ Toxicol Pharmacol. 2016;41:14-21.

41.Wilkins R, Tucci M, Benghuzzi H. The effects of sustained delivery of antioxidants on LPS stimulated raw 264.7 macrophages. Journal of the Mississippi Academy of Sciences. 2014;59:287-92. 42. Adhikari M, Arora R. The flavonolignansilymarin protects enzymatic, hematological, and immune system against $\gamma$-radiation-induced toxicity. Environ Toxicol. 2016;31(6):641-54. 